\title{
Evaluation of the chelating action of methicillin in prolonged experimental metallic mercury poisoning
}

\author{
KRYSTYNA TWARDOWSKA-SAUCHA \\ From the Clinic of Internal and Occupational Diseases, Silesian School of Medicine, Zabrze, Poland
}

\begin{abstract}
Studies were conducted to measure the effect of methicillin on the urinary excretion of mercury in rabbits poisoned for three months by mercury vapour. Simultaneously, studies were done to compare the quantity of eliminated mercury after treatment with methicillin or penicillamine (Cuprenil). The results show that the urinary excretion of mercury in animals treated with either drug was clearly greater than in untreated controls. Furthermore, the quantity of eliminated mercury after treatment with methicillin was significantly greater than after treatment with penicillamine.
\end{abstract}

Mercury poisoning is, after lead poisoning the most frequently encountered type of heavy metal poisoning despite improved work conditions and the isolation of technological processes. One reason for this is the use of mercury in many branches of industry, including the chemical, pharmaceutical, and electrochemical industries, as well as in the production of measuring apparatus and so on.

Metallic mercury enters the body most often in the form of inhaled vapour. It accumulates in the central nervous system and, after prolonged exposure, causes irreversible changes. Neurological, especially cerebral, disturbances predominate in the clinical picture of prolonged mercury poisoning. The treatment of chronic mercury poisoning remains difficult, since so far no effective drug has been found that eliminates or prevents these effects.

There are several drugs with known chelating action with respect to mercury, such as BAL and penicillamine. Their efficacy, however, has been shown only in cases of acute poisoning when administered within a few hours of exposure. In prolonged poisoning the efficacy of these drugs has not been proved and most institutions have stopped using them. Furthermore, these drugs have numerous side effects and are toxic when used in increasing dosage or for a long time.

The use of BAL in the treatment of mercury poisoning decreased after Berlin showed that while BAL caused an increased elimination of mercury in the urine, it also increased the concentration of mercury in the brain. ${ }^{1-3}$ Other, less toxic compounds were, therefore, tested, such as EDTA, DPTA, ${ }^{4}$ tioacetic acid amide, ${ }^{5}$ testosterone propionate, ${ }^{6}$ and penicillamine (Cuprenil, Polfa). Of these, only the last has found wide clinical application.

Penicillamine, a synthetic compound with a high complexing activity to metals, has become the drug of choice in the treatment of Wilson's disease. ${ }^{7}$ It is also used to treat both mercury and lead poisoning. ${ }^{8-10}$ The earlier penicillamine is used in the treatment of experimental animals, the greater is the level of mercury eliminated in the urine. ${ }^{11}$ Similar results have been seen in man. ${ }^{10}$

Numerous side effects, however, have been described with the use of penicillamine such as: agranulocytosis, ${ }^{1213}$ nephrotic syndrome, ${ }^{414}$ and biochemical evidence of pyridoxine deficiency. ${ }^{131516}$ It is thus impossible to use the drug over long periods in prolonged mercury poisoning. In 1970 it was observed that methicillin used to treat a bacterial infection in a patient with mercury poisoning caused an increased elimination of the metal in the urine. Furthermore, as a result of the observation of 15 patients exposed to mercury vapour, the amount of mercury eliminated in the groups treated with either BAL or methicillin was similar. ${ }^{17}$

As a result of the experiments cited above I decided to evaluate the chelating activity of methicillin as determined by the amount of excreted mercury in animals with prolonged mercury poisoning that were treated for two weeks with methicillin. Comparative studies were done with mercury poisoned animals treated with penicillamine (Cuprenil).

\section{Materials and methods}

Forty outbred rabbits, of both sexes, weighing 
$3 \cdot 5-4 \mathrm{~kg}$, and about 18 months old were used in these experiments. Their diet consisted of beets, hay, oats, and green fodder.

At the beginning the animals were divided: 10 control rabbits were kept in toxicological chambers but breathed fresh air and 30 animals were poisoned by exposure to mercury vapour in a concentration of $2 \mathrm{mg} / \mathrm{m}^{3}$ air for three hours daily for three months.

Specially constructed toxicological chambers were used for this purpose. The exchange of air in the chambers ensured the complete removal of the metabolic products of the rabbits $\left(\mathrm{CO}_{2}, \mathrm{NH}_{3}\right)$. The temperature was maintained at $21-22^{\circ} \mathrm{C}$ and the relative humidity was $60-70 \%$. A constant concentration of mercury was obtained by introducing air into glass flasks by means of an electric blower. The air, passing at a constant flow of about $50 \mathrm{l} / \mathrm{min}$, entered a system of tubes, the outlets of which were submerged in the metallic mercury. As the mercury vaporised, it saturated the compressed air passing through it. To maintain a constant level of mercury in the flasks at any given time, the distilling flasks with the mercury were placed in an ultrathermostat which maintained a steady temperature of vaporisation. The mixture of air and mercury was then conducted into the toxicological chambers by a system of tubes and vents. During the experiment the concentration of mercury vapour was measured by the method of Dutkiewicz. $^{18}$

After three months the exposure to mercury was stopped. The 30 mercury poisoned animals were divided into three groups, each consisting of 10 animals:

Group 2 was given no treatment. Groups 3 and 4 were given the following treatment daily for 15 days:

Group 3-Methicillin (Chinoin), intramuscular injection of $100 \mathrm{mg} / \mathrm{kg}$; this represented $0.23 \mathrm{mM} / \mathrm{kg}$ body weight.

Group 4-Penicillamine (Cuprenil, Polfa), $68.6 \mathrm{mg} / \mathrm{kg}$ through a stomach tube; this represented $0.46 \mathrm{mM} / \mathrm{kg}$ body weight, or twice the dosage of methicillin.

Before the beginning of the experiment, for three consecutive days during the experiment, and on days $1,2,3$, and 13,14, 15 after the end of the exposure to mercury, the animals were placed in special metabolic cages and the volume of urine excreted in 24 hours was measured. The concentration of mercury in the urine was measured by the dithizone method. ${ }^{19}$ The importance of the results was determined by Student's $t$ test ${ }^{20}$ comparing the amount of excreted mercury in untreated poisoned animals (group 2) with the amount excreted by animals treated with either methicillin (group 3) or penicillamine (group 4).

To circumvent the errors that could be made during the daily collection of urine, the concentration of mercury in the urine was converted into grams cre- $\frac{2}{3}$
atinine as determined by the method of Rehberg- $\frac{\Phi}{1}$ Folin. ${ }^{21}$

\section{Results}

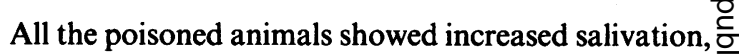
growing apathy, and loss of appetite. During the $\frac{\overline{\bar{c}}}{\overline{0}}$ experiment the animals also experienced loss of hair, $\stackrel{\mathbb{Q}}{\varrho}$ increased diuresis, and showed a slight loss of weight.

The excretion of mercury in the urine during the ${ }^{\infty}$ three month experiment in all animals poisoned with $\vec{\circ}$ mercury was between 31.4 and $613.1 \mu / \mathrm{g}$ creatinine, $\vec{\overrightarrow{ }}$ with an average of about $320 \mu / \mathrm{g}$ creatinine. No mer- $\omega$ cury was found in the urine of the control animals.

The amount of excreted mercury fluctuated during $\frac{\mathbb{}}{3}$ the two weeks after the end of the exposure to mercury depending on the day of observation and the drug used.

In the animals in group 2 the excretion of mercury decreased in the first three days after the end of the exposure to mercury and was between 82.11 and $171 \cdot 18$ (average 120$) \mu / \mathrm{g}$ creatinine.

Animals in group 3 excreted about three times as $\frac{\mathbb{D}}{\mathrm{O}}$ much mercury on the first, second, and third days of $\frac{\overrightarrow{\mathbb{Q}}}{3}$ treatment as the untreated animals; levels ranged from 268.78 to 376.85 (average 320.0 ) $\mu / \mathrm{g}$ creatinine.

In animals of group 4 (treated with penicillamine) $\overrightarrow{0}$ there was a large increase in the level of mercugo excreted on the first day after the beginning of treat. ment (average about $413.58 \mu / \mathrm{g}$ creatinine) but then decreased dramatically on days 2 and $3,91 \cdot 6,94: 5$ (average 90) $\mu / \mathrm{g}$ creatinine.

During the second week after exposure to mercury, the level in the untreated animals (group 2) was between 131.28 and $202.46 \mu / \mathrm{g}$ creatinine. At the same time the animals treated with methicillin excreted 97.85-168.2 $\mu / \mathrm{g}$ creatinine; those treated with penicillamine excreted $131.61-266.3 \mu / \mathrm{g}$ creatinine (table 1, figure).

During the six days of observation the animals in group 2 (untreated) excreted a total of $845.02 \mu / \mathrm{g}$ creatinine, in group 3 (methicillin) $1356.46 \mu / \mathrm{g}$ creatinine, and in group 4 (penicillamine) $1195 \cdot 21 \mu / \mathrm{g}$ creatinine (table 1).

Statistical analysis of these results showed that the $\frac{}{3}$ amount of mercury excreted in the urine of the ani- $D$ mals treated with methicillin or penicillamine was significantly greater than in the untreated animals. N Furthermore, the amount of mercury excreted by ani- o mals treated with methicillin was significantly greater than that excreted by those treated with penicillamine (table 2).

\section{Discussion}

The evaluation of the effect of methicillin and penicil- 
Table 1 Urinary excretion of mercury ( $\mu / g$ creatinine) in rabbits with prolonged exposure to mercury vapour in untreated animals (group 2), animals treated with methicillin (group 3), and animals treated with penicillamine (Cuprenil) (group 4 )

\begin{tabular}{|c|c|c|c|}
\hline $\begin{array}{l}\text { Day of evaluation of } \\
\text { excretion mercury in } \\
\text { urine after exposure } \\
\text { to mercury }\end{array}$ & $\begin{array}{l}\text { Untreated animals } \\
\text { (group 2) } \\
\text { arithmetic mean } \\
(n=10)\end{array}$ & $\begin{array}{l}\text { Animals treated with } \\
\text { methicillin (group 3) } \\
\text { arithmetic mean } \\
(n=10)\end{array}$ & $\begin{array}{l}\text { Animals treated with } \\
\text { penicillamine (group 4) } \\
\text { arithmetic mean } \\
(n=10)\end{array}$ \\
\hline $\begin{array}{l}1 \\
2 \\
3 \\
13 \\
14 \\
15 \\
\text { Total }\end{array}$ & $\begin{array}{c}171 \cdot 18 \mu / \mathrm{g} \mathrm{cr} \\
104.10 \mu / \mathrm{g} \mathrm{cr} \\
82.4 \mu / \mathrm{g} \mathrm{cr} \\
131.28 \mu / \mathrm{g} \mathrm{cr} \\
153.6 \mu / \mathrm{g} \mathrm{cr} \\
202.46 \mu / \mathrm{g} \mathrm{cr} \\
845.02 \mu / \mathrm{g} \mathrm{cr}\end{array}$ & $\begin{array}{c}308.35 \mu / \mathrm{g} \mathrm{cr} \\
376.85 \mu / \mathrm{g} \mathrm{cr} \\
268.76 \mu / \mathrm{g} \mathrm{cr} \\
168.2 \mu / \mathrm{g} \mathrm{cr} \\
97.85 \mu / \mathrm{g} \mathrm{cr} \\
136.45 \mu / \mathrm{g} \mathrm{cr} \\
1356.46 \mu / \mathrm{g} \mathrm{cr}\end{array}$ & $\begin{array}{c}413.58 \mu / \mathrm{g} \mathrm{cr} \\
91.6 \mu / \mathrm{g} \mathrm{cr} \\
94.5 \mu / \mathrm{g} \mathrm{cr} \\
131.61 \mu / \mathrm{g} \mathrm{cr} \\
266.35 \mu / \mathrm{g} \mathrm{cr} \\
197.57 \mu / \mathrm{g} \mathrm{cr} \\
1195.21 \mu / \mathrm{g} \mathrm{cr}\end{array}$ \\
\hline
\end{tabular}

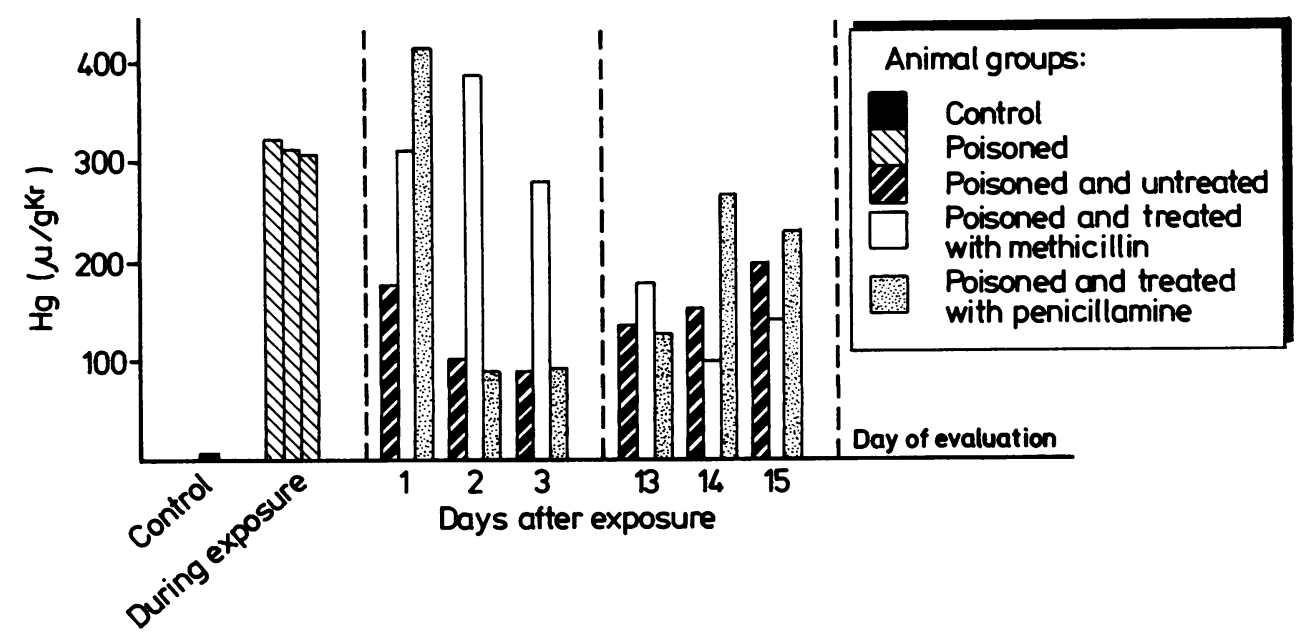
Average urinary excretion of mercury ( $\mu / g$ creatinine) in rabbits during chronic exposure to mercury vapour
evaluated on three days during poisoning, then on days $1,2,3,13,14$, and 15 after exposure in each group.

lamine on the excretion of mercury in animals with prolonged mercury poisoning has shown that both drugs have strong complexing properties and help to eliminate mercury from the body. The amount of excreted mercury in animals treated with methicillin was high, especially in the first week of treatment.
After treatment with methicillin the level of excreted mercury remains fairly constant, but there is more fluctuation after treatment with penicillamine. During the second week of methicillin treatment the level of excreted mercury is less than in the other two groups of animals. One reason may be a high level of

Table 2 Amount of mercury excreted in the urine in animals treated with methicillin (group 3), penicillamine (4), and untreated (2) during two weeks after being exposed to mercury (data converted into $\mu / g$ creatinine)

\begin{tabular}{|c|c|c|c|c|c|c|c|}
\hline $\begin{array}{l}\text { Statistical data } \\
\text { Group of animals }\end{array}$ & $\begin{array}{l}\text { Amount of excreted } \\
\text { mercury on days } \\
1,2,3,13,14,15 \\
\text { after cessation of } \\
\text { mercury exposure }\end{array}$ & $\begin{array}{l}\text { Differences } \\
\text { between } \\
m_{1} \text { and } m_{2}\end{array}$ & ${ }_{t}^{t}$ & $\begin{array}{l}\text { Statistical } \\
\text { relevance } \\
(\alpha)\end{array}$ & $\begin{array}{l}\text { Differences } \\
\text { between } \\
m_{1}-m_{3}\end{array}$ & $\begin{array}{l}t \\
\text { test }\end{array}$ & $\begin{array}{l}\text { Statistical } \\
\text { relevance } \\
(\alpha)\end{array}$ \\
\hline \multirow{3}{*}{$\begin{array}{l}\text { Untreated } \\
\text { from...to } \\
m_{1}, \pm \delta \\
\text { Methicillin treated } \\
\text { from...to } \\
\mathrm{m}_{2}, \pm \delta \\
\text { Penicillamine treated } \\
\text { from...to } \\
\mathrm{m}_{3}, \pm \delta\end{array}$} & $\begin{array}{r}39.9-223.7 \\
140.85 \pm 52.0\end{array}$ & & & & & & \\
\hline & $\begin{array}{cc}48.8 & -550.0 \\
226.07 & \pm 130.54\end{array}$ & $85 \cdot 22$ & $-4 \cdot 20$ & $\alpha<0.001$ & & & \\
\hline & $\begin{array}{c}15 \cdot 2-647 \cdot 0 \\
199 \cdot 20 \pm 134 \cdot 26\end{array}$ & & & & 58.45 & $-2 \cdot 81$ & $\alpha<0.01$ \\
\hline
\end{tabular}


mercury excreted on those days when measurements were not taken. Future experiments should be conducted with daily measurements of excreted mercury.

The total amount of mercury in the animals treated with methicillin was, however, higher than in those treated with penicillamine. It is important to note that the amount of methicillin used, when converted to $\mathrm{mM} / \mathrm{kg}$ body weight was half that of penicillamine $(0.23 \mathrm{mM}$ and $0.46 \mathrm{mM})$.

While the mechanism of the chelating action of methicillin is not known, the complexing activity of penicillamine has been known for a long time and this drug has had numerous clinical applications. $^{7-101422}$ The clinical use of penicillamine, however, has also shown that this drug has many side effects when used for a long period. ${ }^{213141623}$ Methicillin appears to be free of side effects, with the exception of possible sensitisation. These experiments suggest that because of the great ability of methicillin to complex to mercury and to cause its elimination from the body this drug may be valuable in treating prolonged mercury poisoning.

\section{References}

1 Berlin M, Lewander T. Increased brain uptake of mercury caused by BAL in mice given mercuric chloride. Acta Pharmacol 1965;22:1-7.

2 Berlin M, Ullberg S. Increased uptake of mercury in mouse brain caused by 2,3-dimercaptopropanol. Nature 1963;197:84-5.

3 Magos L. Effect of 2,3-dimercaptopropanol (BAL) on urinary excretion and brain content of mercury. $\mathrm{Br} \mathrm{J}$ Ind Med 1968;25:152-3.

4 Truhaut R, Boudéne CL, Jouany JM. Recherches sur les effects detoxicants de certains chélatures aprés intoxication du rein isolé de lapin par des sols de mercure. Ann Biol Clin 1968;26:1267-73.

5 Dutkiewicz T, Ogiński M, Trojanowska B. Attempt of mobilization of mercury from the body using tioacetic acid amide.
Med Pr 1964;15:231-5.

6 Levy RP, Moir TW, Miller M. BAL and testosterone propionate in the treatment of mercury chloride poisoning. Proc Soc Exp Biol Med 1959;73:498-500.

7 Walshe JM. Treatment of Wilson's disease with penicillamine. Lancet 1960; $1: 188-92$.

8 Boulding JE, Baker RA. Treatment of metal poisoning with penicillamine. Lancet 1957;ii:985.

9 Pagnotto LD, Brugschi HG, Elkins HB. Treatment of chronic $\overline{\bar{c}}$ mercurialism with $\mathrm{N}$-acetyl-penicillamine. Am Ind Hyg Assoc $J \vec{\nabla}$ 1960;21:419-22.

10 Parameshvara V. Mercury poisoning and its treatment with N- N acetyl-D,L-penicillamine. Br J Ind Med 1967;24:73-6.

11 Nawaszin SM, Zukow WG, Bieriezina EK. Ekspierimientalnoje $\vec{\circ}$ izuczienije D-penicillamina. Antibiotiki 1969;5:436-8.

12 Corcos JM, Soler-Bechara J, Mayer K, Freyberg R, Goldstein R, $\vec{\omega}$ Jaffe I. Neutrophilic agranulocytosis during administration of $\underset{ }{ }$ penicillamine. JAMA 1964;189:265-8.

13 Francois R, Germain D, Pellet H, Moreau P, Pouillaude JM, Collard N. Acrodynie. (Etude comparée de différents chelateurs agranulocytose curable au cours d'un traitment par la $\vec{\omega}$ pénicillamine.) Pédiatrie 1967;22:341-6.

14 Yonis IZ, Karp M. Chelating agents in Wilson's disease. Lancet कृ 1963;ii:689. 15 Asatoor AM. Pyridoxine deficiency in the rat produced by
D-penicillamine. Nature $1964 ; 203: 1382-4$.

16 Kuchinskas EJ, Horvath A, du Vigneaud V. An antivitamin $\mathbf{B}_{\mathbf{6}} \overrightarrow{\mathrm{C}}$ action of L-penicillamine. Arch Biochem 1957;68:69-75.

17 Kośmider S, KXopotowski J. Behandlung chronischer Quecksillbervergiftungen mit Methycyllin. International Archiv für $\mathbb{D}$ Arbeitzmedizin 1970;27:228-33.

18 Dutkiewicz T, Kęsy-Dąbrowska I, Piotrowski J. Oznaczanie zwiazków toksycznych $w$ powietrzu. PZWL Warszawa 1962:126-8.

19 Dutkiewicz T, Piotrowski J, Kęsy-Dąbrowska I. Chemicz@̊ œ badanie materiału biologicznego $w$ toksykolog przemysłowej. PZWL Warszawa 1964:196-8.

20 Hill AB. Statystyka dla lekarzy. PWN Warszawa 1962; 133-4

21 Kokot F. Metody badań laboratoryjnych stosowanych w Klinice. VII. Biochemiczne metody badania krwi. PZWL Warszawa 1963:243-4.

22 Hamann D, Unterspann S. Tierexperimentelle Untersuchungen $\mathbb{D}$ zur Dekorporation von Radioquecksilber mittels D-Penizillamin. Radiobiol Radiother 1968;9:711-6.

23 Jaffe IA, Altman K, Merryman P. The antipyridoxine effect of penicillamine in man. J Clin Invest 1964;43:1869-71. 